COMU J Mar Sci Fish

2020 3(2): $95-101$

DOI: $10.46384 /$ jmsf.794629
Journal Home-Page:

http://jmsf.dergi.comu.edu.tr

Online Submission:

http://dergipark.gov.tr/jmsf

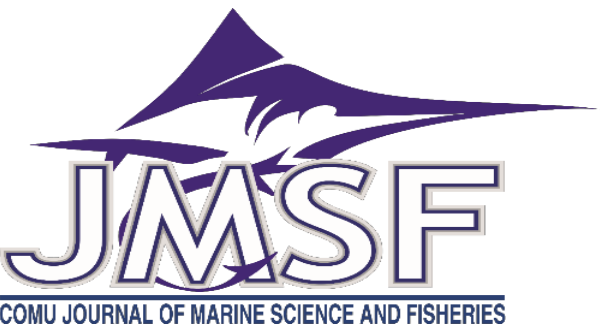

ARAŞTIRMA MAKALESI

\title{
Larval Morphological Development and Seasonal Variation of the Mediterranean Sand Eel, Gymnammodytes cicerelus (Rafinesque, 1810) in the Shallow Waters of Gökçeada Island, North Aegean Sea
}

\author{
İsmail Burak Daban *, Ali İşmen \\ Marine Science and Technology Faculty, Fisheries Department, University of Çanakkale, Turkey \\ Correspondent: burakdaban@gmail.com

How to cite this article: Daban, İ. B. \& İşmen, A., (2020). Larval morphological development and seasonal variation of the Mediterranean Sand Eel, Gymnammodytes cicerelus (Rafinesque, 1810) in the shallow waters of Gökçeada Island, North Aegean Sea. COMU J. Mar. Sci. Fish, 3(2): 95-101. DOI: 10.46384/jmsf.794629

Abstract: Mediterranean sand eel, Gymnammodytes cicerelus (Rafinesque, 1810) is a demersal subtropical fish species belonging to the family Ammodytidae. In this study, the morphological development and temporal variations of Mediterranean sand eel larvae were studied. Ichthyoplankton samples were collected between September 2015 and April 2016 in the shallow waters of the Gökçeada Island, northern Aegean Sea. Samples were collected with horizontal tows, using a WP-2 plankton net $(57 \mathrm{~cm}$ frame diameter equipped with a $500 \mu \mathrm{m}$ mesh, $3 \mathrm{~m}$ total length). Early life stages were photographed and morphological features of individuals between 2.73$7.91 \mathrm{~mm}$ in standard length were described comprehensively. It was determined that spawning occurred between November and February and peaked in December. Larval abundance ranged between 6.36 and 69.96 individuals $/ 1000 \mathrm{~m}^{3}$. In this study, the abundance and distribution of the species in the Mediterranean was revealed for the first time.

Keywords: Identification, Spawning Season, Melanophore, Abundance

\section{Gökçeada Kıyı Sularında Bulunan Kum Yılan Balı̆̆ı, Gymnammodytes cicerelus (Rafinesque, 1810)'nın Larval Morfolojik Gelişimi ve Mevsimsel Değișimi}

\begin{abstract}
Özet: Kum yılan balığı, Gymnammodytes cicerelus (Rafinesque, 1810), Ammodytidae familyasına ait olan demersal ve subtropical bir türdür. Bu çalışmada kum yılan balığı larvalarının morfolojik gelişimi ve zamansal değişimi çalıșılmıştır. İhtiyoplankton örnekleri Gökçeada kıyı sularından Eylül 2015 ile Nisan 2016 tarihleri arasında toplanmıştır. Örneklemeler horizontal çekimler ile WP-2 tip plankton kepçesi (500 $\mu$ m netle donatılmış $57 \mathrm{~cm}$ çember çapına ve $3 \mathrm{~m}$ toplam net uzunluğuna sahip) ile gerçekleştirilmiştir. Erken yaşam evreleri fotoğraflanmış ve 2.73-7.91 mm standart boy aralığındaki bireylerin morfolojik değișimler kapsamlı olarak tanımlanmıştır. Üreme sezonunun Kasım ile Şubat arasında olduğu, üremenin Aralık ayında pik yaptığı tespit edilmiştir. Larval bolluk değeri birim alanda 6.36 ile $69.96 \mathrm{n} / 1000 \mathrm{~m}^{3}$ arasında değişmiştir. Bu çalışmada ilk kez türün Akdeniz’de-ki larval bolluk ve dağılımı ortaya konmuştur.
\end{abstract}

Anahtar Kelimeler: Tayin, Üreme Sezonu, Melanafor, Bolluk 


\section{Introduction}

Mediterranean sand eel, Gymnammodytes cicerelus (Rafinesque, 1810) is a demersal subtropical fish species belonging to the family Ammodytidae which has 23 species all around the world (Nelson, 2006). It's known as a short-lived forage species and distributed in the eastern Atlantic and the Mediterranean Sea (Quéro, 1990). and It is commonly found over shell-gravel and coarse sand bottoms (Wheeler, 1979). Mediterranean sand eel is generally caught as live bait for longline fishery but is also consumed as meal and used for fish oil production (Reay, 1970). Sand eel is commonly targeted in Catolonia by traditional fishery boats called "sonsera" (Lleonart et. al., 2014). Despite its abundance, biological parameters of sand eel are_quite rare all around the world. It has demersal eggs which are layed on sand and gravel (Reay, 1986). Spawning of the sand eel occurs between November and January in the Mediterranean Sea (Bauchot, 1987) and November to February around Catolonia costs (Lleonart et. al., 2014). Age at first maturity was detected as 0 -years by Lleonart et al. (2014). In Turkish waters, Erazi (1942), Devedjian (1915) and Slastenenko (19551956) reported its distribution, but provided no precise locality information. Adultswere found on sandy bottoms around shallow waters of the Erdek Bay, Marmara Sea (Keskin, 2007) and central Black Sea coast of Turkey (Bat et al., 2005).
Information on the early life stages of the Mediterranean and eel is also rare. Some studies were conducted in Medes Islands (Sabates et al., 2003), the Aegean Sea (Caragitsou et al., 1998; Koutrakis et al., 2004; Çoker and Mater, 2006), Marmara Sea (Yüksek et al., 2006) and the Black Sea (Mavruk et al., 2017).

Padoa (1956) reported the morphological characteristics of 7, 11 and $25 \mathrm{~mm}$ SL larvae for the first time. In Turkish waters, Çoker (2013) described the morphology of the larvae of this species which ranged between 3.2 and $3.8 \mathrm{~mm}$ SL in length around Izmir Bay. The aim of this study was to provide more detailed information on early life history of Mediterranean sand eel larvae.

\section{Material and Methods}

Ichthyoplankton samples were collected from northern part of the Gökçeada Island, North Aegean Sea (Figure 1.). The study was carried out with weekly samplings between September 2015 and September 2016. Samples were collected from 3 stations located nearshore (<20 m depth) $\left(40^{\circ} 22^{\prime}-40^{\circ} 23^{\prime} \mathrm{N} ; 2^{\circ} 85^{\prime}\right.$ $25^{\circ} 87^{\prime}$ E). All stations were located in areas characterized by sudden steeping of the seafloor. This area is also exposed to strong northerly winds, with main current direction from from northwest to southeast.

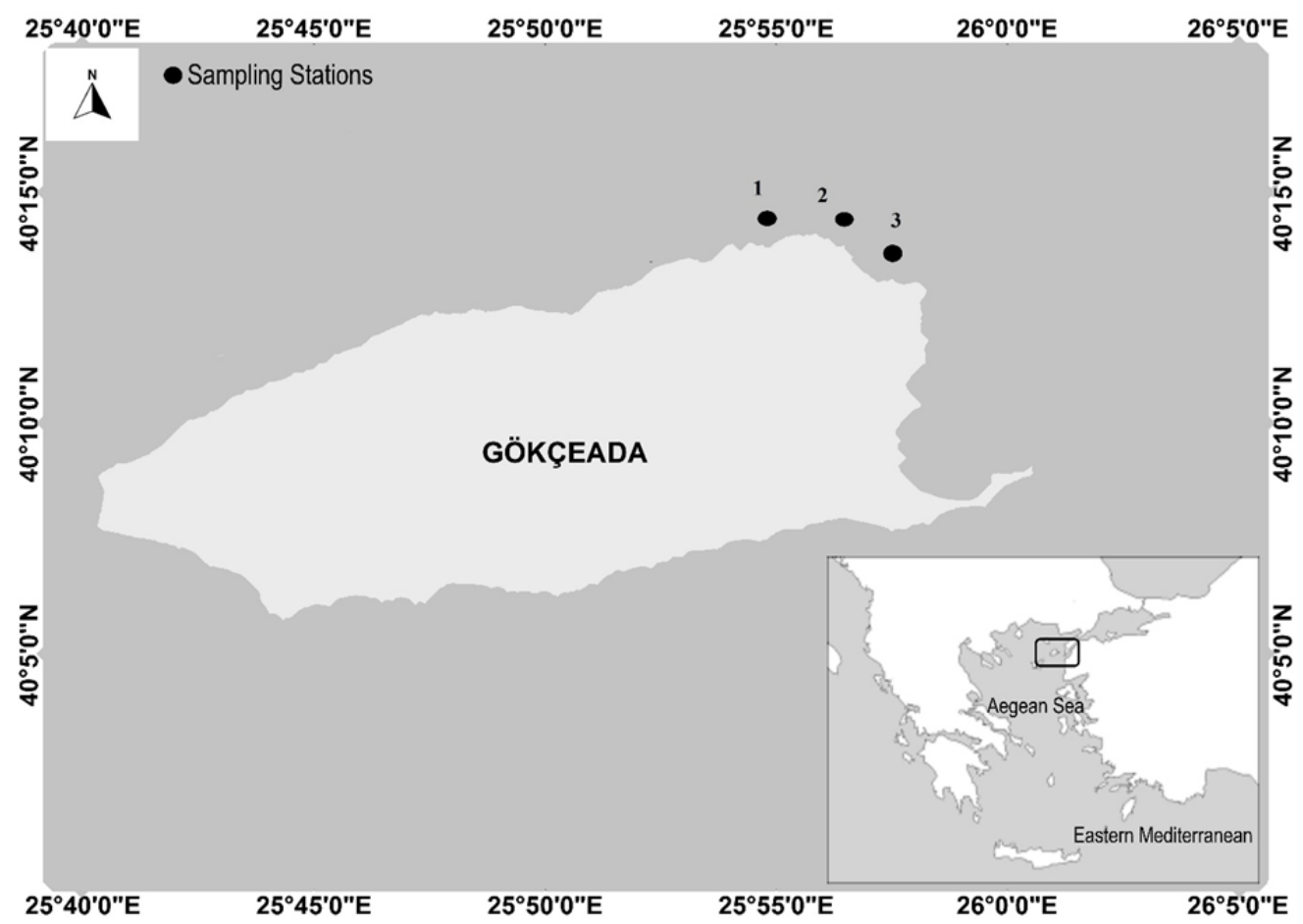

Figure 1. Ichthyoplankton sampling area, North Aegean Sea, Gökçeada, Turkey

Samples were collected using a WP-2 plankton net (57 $\mathrm{cm}$ frame diameter, $500 \mu \mathrm{m}$ mesh size) with horizontal tows which were performed $0.5 \mathrm{~m}$ below the sea surface for a duration of 10 minutes and a vessel speed of 2 knots towards down-current. Samples were fixed with $4 \%$ formaldehyde-sea water 
solution on the vessel. The keys of Padoa (1956), Dekhnik (1973) and Russell (1976) were used for identification of larval sand eels. Larvae were counted and morphological characteristics were recorded under dissecting microscope (Figure 2).

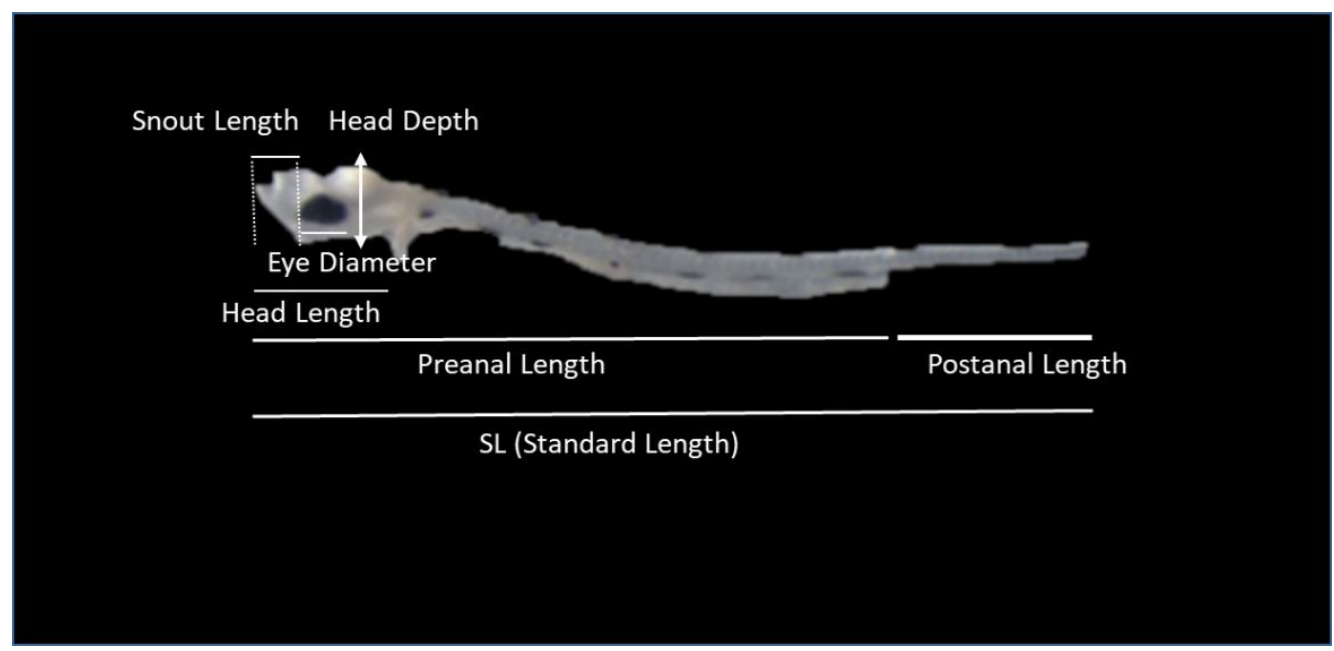

Figure 2. Larval morphological characteristics used in the study

Once larval photographs taken,_larvae were measured using Olympus SZX-7 stereo microscope attached to a camera with Q-Capture Pro 5.1. Imaging System. Densities of fish eggs and larvae (the count per $1000 \mathrm{~m}^{3}$ ) for horizontal tows were calculated as follows:

$$
D=\frac{N}{\mathrm{~V}} * 1000
$$

where $\mathrm{N}$ is the total number of eggs or larvae in each sample and $\mathrm{V}$ is the volume of sampled water $\left(\mathrm{m}^{3}\right)$. Since no flow meter was used in the study, the volume of water that passed through the net, $\mathrm{V}$, was estimated using the following equation:

$$
\mathrm{V}=\mathrm{v} \times \Delta \mathrm{t} \times \mathrm{A}
$$

where $\mathrm{v}=$ average speed through the water during a tow $\left(\mathrm{m} \mathrm{s}^{-1}\right), \Delta \mathrm{t}=$ time of the tow (s), and $\mathrm{A}=$ crosssectional area of the net $\left(\mathrm{m}^{2}\right)$. Densities calculated were considered to represent the minimum ichthyoplankton density per $1000 \mathrm{~m}^{3}$.

\section{Results and Discussion}

A total of 39 Mediterranean sand eel larvae were identified Corresponding to $1.9 \%$ of total larval abundance. Sand eel larvae were found between November and February. Larval abundance peaked in December $\left(69,96 \mathrm{n} / 1000 \mathrm{~m}^{3}\right)$ when sea surface temperature decreased below $16{ }^{0} \mathrm{C}$ (Figure 3). Relatively high abundances were found on January $7^{\text {th }}$ and $15^{\text {th }}$ densities 50,88 and 38,16 larvae/1000 $\mathrm{m}^{3}$, respectively.

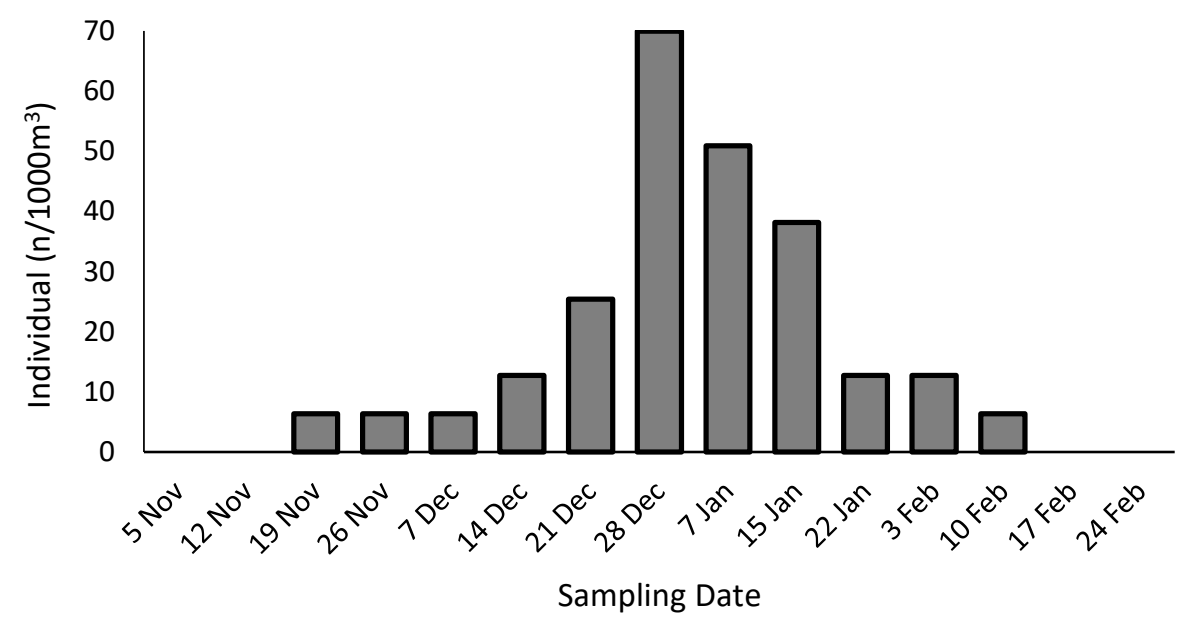

Figure 3. Temporal variations of the Gymnammodytes cicerelus larvae 
Overall, 1 yolk sac, 36 pre-flexion and 2 flexion larvae were identified. The sizes of larvae ranged between $2.73-7.91 \mathrm{~mm}$ in standard lengths (SL) with an average of $4.27 \pm 0.18 \mathrm{~mm}$ SL (mean \pm SE) (Table
1). The body and the gut are elongated. The anus is placed at about $75 \%$ of the SL. Myomer numbers were between $64-66$.

Table 1. Some morphometric measurements of Mediterranean Sand Eel, Gymnammodytes cicerelus (All measurements are in millimeter)

\begin{tabular}{ccccccc}
\hline $\begin{array}{c}\text { Standard } \\
\text { Length }\end{array}$ & $\begin{array}{c}\text { Head } \\
\text { Length }\end{array}$ & $\begin{array}{c}\text { Snout } \\
\text { Length }\end{array}$ & $\begin{array}{c}\text { Preanal } \\
\text { Length }\end{array}$ & $\begin{array}{c}\text { Postanal } \\
\text { Length }\end{array}$ & $\begin{array}{c}\text { Eye } \\
\text { Diameter }\end{array}$ & $\begin{array}{c}\text { Head } \\
\text { Depth }\end{array}$ \\
\hline 2.73 & 0.29 & 0.04 & 2.21 & 0.52 & 0.14 & 0.21 \\
3.18 & 0.38 & 0.05 & 2.08 & 1.1 & 0.15 & 0.27 \\
3.49 & 0.5 & 0.09 & 2.35 & 1.14 & 0.15 & 0.27 \\
3.74 & 0.53 & 0.12 & 2.63 & 1.11 & 0.2 & 0.27 \\
4.08 & 0.61 & 0.15 & 2.67 & 1.41 & 0.24 & 0.37 \\
4.35 & 0.63 & 0.16 & 3.85 & 1.5 & 0.24 & 0.46 \\
4.47 & 0.67 & 0.16 & 3.01 & 1.46 & 0.24 & 0.46 \\
5.64 & 0.79 & 0.2 & 3.78 & 1.86 & 0.25 & 0.59 \\
6.12 & 0.9 & 0.21 & 4.08 & 2.04 & 0.34 & 0.59 \\
7.91 & 1.29 & 0.4 & 5.38 & 2.53 & 0.39 & 0.59 \\
\hline
\end{tabular}

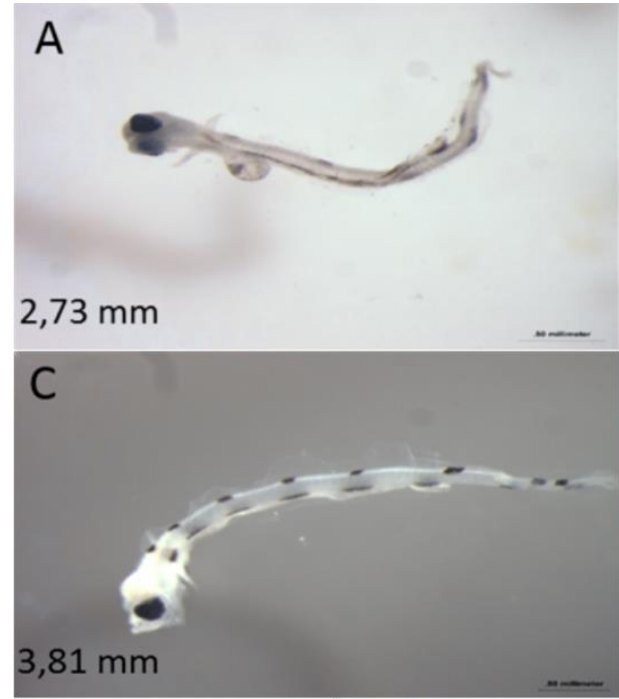

B
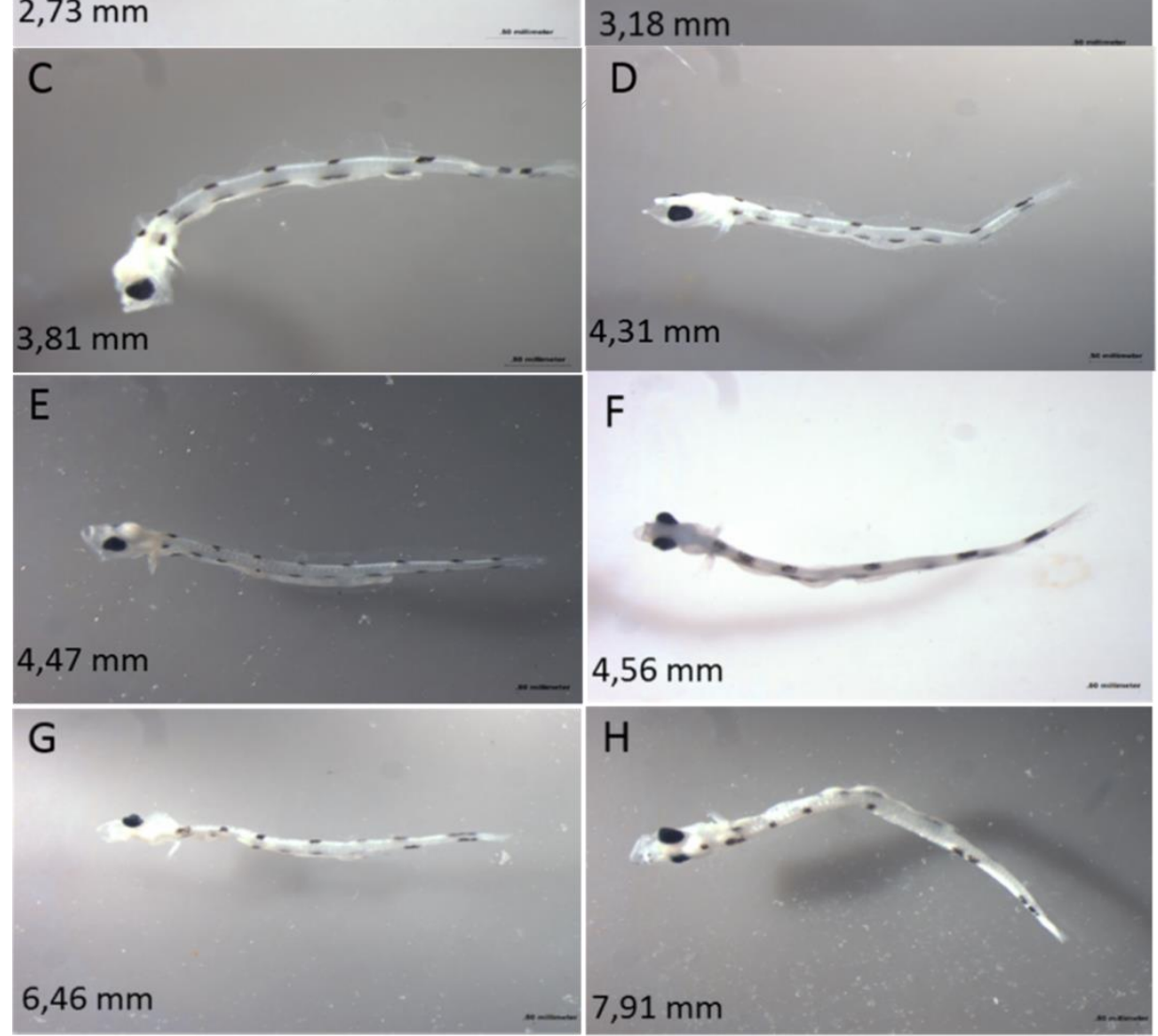

Figure 4. Morphological development of Mediterranean Sand Eel, Gymnammodytes cicerelus from yolc-sac larvae to the flexion larvae. Stage A: newly hatched yolk sac larvae, Stage A-F: preflexion larvae, and Stage G-H: early flexion larvae 
With regard to the morphological characteristics and pigmentation on the body, some differences were observed. On yolk sac larvae with $2.73 \mathrm{~mm} \mathrm{SL,} 5$ melanophores on dorsal side and 2 melanophores on post anal ventral were observed. In addition, pigmentation was observed on the gut, yolk sac and on ventral side of the primordial fin. There were no melanophores on the head, mandibular, lower jaw angle and upper jaw. Snout length was relatively short. In larvae smaller than $3.74 \mathrm{~mm} \mathrm{SL}$, there were only two melanophores on the post anal ventral and 6-7 melanophores on the dorsal side. In larvae with 3.81 $\mathrm{mm}$ SL, all individuals had 7 melanophores on the dorsal and 3 melanophores on the post anal ventral. In larvae larger than $4.24 \mathrm{~mm} \mathrm{SL}$, it was observed that the upper jaw- was protruted frontward. In larvae smaller than $6.24 \mathrm{~mm}$ SL, pigmentation on the primordial fin was observed but the anus did not reach to the outer edge of the primordial fin. Primordial fin disappeared in larvae larger than $6.24 \mathrm{~mm}$ SL. In flexion larvae with7.91 $\mathrm{mm}$ SL, there were 9 melanophores on the dorsal side of the body with a single melanophore located on the head. Pigmentation was observed -for the first time on the mandibular and upper jaw at this stage (Figure 4).

Similar to the findings in the present study, reported frequencies of sand eel larval occurrence were lower in earlier studies (Granata et al., 2010; Lynam et al., 2013; Sabates et al., 2003; Koutrakis et al., 2004). This may be due to short life span of sand eels (Lynam et al., 2013), their restricted spawning season and predation by the other fish such as Gadoids (Greenstreet et al., 1998), as well as by seabirds (Daunt et al., 2008), and marine mammals (Thompson et al., 2007).

In our study, relatively higher abundances were observed on December $28^{\text {th }}$ and January $7^{\text {th }}$ in the water column. It is known that the abundance of sand eel larvae increase with decreasing sea water temperature and can dominate the ichthyoplankton in some areas. For example, Ellacuria (2015) detected the peak season in March when sea water temperature reached the seasonal minimum $\left(<14^{\circ} \mathrm{C}\right)$ value in the Balearic Sea. In addition, Sabates et al. (2003), observed this larvae in the winter period between January and March. In our study, spawning occurred earlier than that reported in Medes Island. Sand eel larvae were first observed on November $19^{\text {th }}$ when water temperature was $16{ }^{\circ} \mathrm{C}$ and peaked on December $28^{\text {th }}$ at $12.8^{\circ} \mathrm{C}$. Overall, in terms of temperature and abundance, our results were in accordance with the findings of others.

Koutrakis et al. (2004) reported that sand eels were relatively rare in the ichthyoplankton of Strymonikos and Ierissos Gulfs (NW Aegean Sea). They observed that sand eel larvae occur only in March. In our study spawning period of sand eels ended in mid February when the sea surface temperature dropped to $11^{\circ} \mathrm{C}$. Short and closely spaced spawning periods within a broad geographical area reflect necessity of specific environmental conditions required for reproduction of this species. In terms of sea surface temperature, the results of our study in the north Aegean Sea showed that temperature range for spawning of sand eels is 11 $-16{ }^{\circ} \mathrm{C}$

In the present study, sampling was carried out in a limited geographical area (northern part of the Gökçeada Island) and therefore, precise information on spatial distribution for this species is not known. Suitable habitats such as sandy beaches are available around Gökçeada island. Further surveys encompassing broader areas are required to determine larval distribution and evaluate drifting patterns of this species.

Information about the morphological development and growth patterns of young fish is important for fisheries management and aquaculture (Chatain, 1994; Koumoundouros et al., 1994, 1999; Bengtson, 1999). Sand eel was listed as Least Concern in International Union for Conservation of Nature's (IUCN, 2020) Red List. Understanding early life history of this species may contribute to conservation of stocks. Lesser known species, such as sand eel, may become more valuable in conjunction with decreasing stocks of available economical species due to high fishing pressure. Besides, early life history of all species is critical to understand due to their ecological impacts in the food chain. The detailed morphological development given in this study may be useful for ichthyoplankton researchers as it will help identification of larval stages and contribute to spawning period of adult sand eels.

\section{Acknowledgement}

Data in this study are part of $\mathrm{PhD}$ thesis of İsmail Burak Daban. The authors would like to thank Assoc. Prof. Dr. Ahsen Yüksek for valuable contributions in identifying fish larvae. Thanks are extended to Kamil Çakır and Captain Yılmaz Tokoğlu who helped in the field samplings.

\section{References}

Bat L., Erdem Y., Ustaoğlu S., Yardım Ö. \& Satılmış H. H., 2005. A Study on the Fishes of the Central Black Sea Coast of Turkey. J. Black Sea/Mediterranean Environment, 11: 281 -296.

Bauchot M. L. 1987. Poissons osseux. p. 891-1421. In: Fischer W., Bauchot M.L. and Schneider M. (eds.) Fiches FAO d'identification pour les besoins de la pêche. (rev. 1). Méditerranée et mer Noire. Zone de pêche 37(II). Commission des Communautés Européennes and FAO, Rome.

Bengston V. L., Schaie K.W., 1999. Handbook of theories of aging Springer, New York.

Caragitsou E., Siapatis A., Papaconstantinou C., 1998. Vertical Distribution and Migration of Fish Larvae 
During the Night in the N.W. Aegean Sea. Rapp. Comm. int. Mer Médit., 35.

Chatain B., 1994. Abnormal swimbladder development and lordosis in sea bass (Dicentrarchus labrax) and sea bream (Sparus aurata) Aquaculture, 119 pp. 371-379

Çoker, T. 2003. The morphology and ecology of the pelagic eggs and larvae of teleost fishes in İzmir Bay (In Turkish). E.Ü. Fen Bilimleri Enstitüsü, Doktora Tezi, $539 \mathrm{~s}$.

Çoker T., Mater S., 2006. İzmir Körfezi İhtiyoplanktonu (1974-2005) Türleri. E.U. Journal of Fisheries\& Aquatic Sciences, 23: (3-4), 463472 pp. (in Turkish).

Daunt F., Wanless S., Greenstreet S. P. R., Jensen H., Hamer K. C., Harris, M. P., 2008. The impact of the sandeel fishery closure on seabird food consumption, distribution and productivity in the northwestern North Sea. Canadian Journal of Fisheries and Aquatic Science, 65: 362-381.

Dekhnik T. V., 1973. Black Sea ichthyoplankton (Ikhtioplankton chernogo moria). Naukova Dumka, Kiev, 236 p. [in Russian].

Devedjian K., 1915. Balik ve balikçilik [Fish and fisheries]. Istanbul, $440 \mathrm{pp}$. [in Ottoman].

Ellacuría I. Á., 2015. Multiscale Environmental Ichthyoplankton Assemblages Relationships in the Balearic Sea. PhD Thesis, Universitat de les Illes Balears, 248 pp.

Erazi R. A. R., 1942. Marine fishes found in the Sea of Marmara and in the Bosphorus. Revue de la Faculte des Sciences de L'universite D'Istanbul, 7(1/2), 103-114.

Greenstreet S. P. R., McMillan J. A., Armstrong F., 1998. Seasonal variation in the importance of pelagic fish in the diet of piscivorous fish in the Moray Firth, NE Scotland: a response to variation in prey abundance? ICES Journal of Marine Science, 55: 121-133.

Granata A., Cubeta A., Minutoli R., Bergamasco A., Guglielmo L., 2010. Distribution and abundance of fish larvae in the northern Ionian Sea (Eastern Mediterranean). Helgoland Marine Research, Springer Verlag, 65 (3), pp.381-398. .

IUCN, 2020. The IUCN Red List of Threatened Species. Version 2020-2. https://www.iucnredlist.org. Downloaded on 05 June 2020.

Keskin C., 2007. Temporal variation of fish assemblages in different shallow-water habitats in Erdek Bay, Marmara Sea, Turkey. J. Black Sea/Mediterr. Environ. 13,215-234.

Koumoundouros G., Kiriakos Z., Divanach P., Kentouri M., 1994. Morphometricrelationships as criteria for the evaluation of culture conditions of gilthead sea bream (Sparus aurata) at the larval stage Kestemont P., Muir J., Sevila F., Williot P. (Eds.), Measures for Success, CEMAGREF, Bordeaux (1994), pp. 199-205

Koumoundouros G., Divanach P., Kentouri M., 1999. Osteological development of the vertebral column and of the caudal complex in Dentex dentex J. Fish Biol., 54, pp. 424-436

Koutrakis E. T., Kallianiotis A. A., Tsikliras A. C. 2004. Temporal patterns of larval fish distribution and abundance in a coastal area of northern Greece. Sci. Mar. 68(4):585-595.

Lleonart J, Demestre M, Martín P, Rodón J, SainzTrápaga S, Sánchez P, Segarra I, Tudela S., 2014. The co-management of the sand eel fishery of Catalonia (NW Mediterranean): the story of a process. Scientia Marina 78 S1: 87-93.

Lynam C. P., Halliday N. C., Hoffle H., Wright P. J., van Damme C. J. G., Edwards M., Pitois S.G., 2013. Spatial patterns and trends in abundance of larval sandeels in the North Sea: 1950-2005. ICES Journal of Marine Science, 70(3), $540-553$. doi:10.1093/icesjms/fst006.

Mavruk, S., Ak Orek, Y., 2017. A Synthesis of Ichthyoplankton Studies in Turkish Part of the Black Sea, in: Sezgin, M., Bat, L., Ürkmez, D., Arıcı, E., Öztürk, B. (Eds.), Black Sea Marine Environment: The Turkish Shelf. Turkish Marine Research Foundation, Istanbul, pp. 567-587.

Nelson J. S., 2006. Fishes of the World. Wiley \& Sons Inc. 4th edition, $601 \mathrm{pp}$.

Olivar M. P., Quilez G., Emelianov M., 2003. Spatial and temporal distribution and abundance of European hake, Merluccius merluccius, eggs and larvae in the Catalan coast (NW Mediterranean). Fisheries Research 60, 321-331.

Padoa E., 1956. In uova, larve e stadi giovanili di Teleostei. Fauna Flora Golfo di Napoli, Monogr. $38,(3 / 2), 687-774$

Reay P. J., 1970. Synopsis of biological data on North Atlantic sandeels of the genus Ammodytes ( $A$. tobianus, A. dubius, A. americenus and A. marinus) FAO Fish. Synops. (82): 48 pp.

Reay P. J., 1986. Ammodytidae. p. 945-950. In: Whitehead P. J. P., Bauchot M. L., Hureau J. C., Nielsen J., Tortonese E. (eds.) Fishes of the northeastern Atlantic and the Mediterranean. UNESCO, Paris. Vol. 2.

Russell F. S., 1976. The eggs and planktonic stages of British marine fishes. Academic Press, New York.

Sabatés A., Zabala M., García-Rubies A., 2003. Larval fish communities in the Medes Islands Marine 
Reserve (North-west Mediterranean). Journal of Plankton Research, 25(9): 1035-1046.

Thompson P., Ingram S., Lonergan M., Northridge S., 2007. Climate change causing starvation in harbour porpoises? Biology Letters, 3: 533-534.

Quéro J. C. 1990. Ammodytidae. p. 920. In: Quéro J. C., Hureau J. C., Karrer C. Post A., Saldanha L. (eds.) Check-list of the fishes of the eastern tropical Atlantic (CLOFETA). JNICT, Lisbon; SEI, Paris; and UNESCO, Paris. Vol. 2.

Slastenenko E. (1955-1956) Karadeniz havzasi baliklari [Fishes of Black Sea basin]. Et ve Balik Kurumu Yayinlari, Istanbul, 711 pp. [in Turkish].

Yüksek A., Okuş E., Yılmaz I. N., Aslan Yılmaz A., Taş S., 2006. Changes in biodiversity of the extremely polluted Golden Horn Estuary following the improvements in water quality. Marine Pollution Bulletin, 52: 1209-1218.

Wheeler A., 1979. Ammodytidae. In: Hureau J.C. and Monod Th. (eds.) Check-list of the fishes of the north-eastern Atlantic and of the Mediterranean (CLOFNAM). UNESCO, Paris. Vol. 1. p. 446448. 